\title{
Psychoanalysis, a gay spatial science?
}

\author{
Paul Kingsbury \\ Department of Geography, Miami University, Oxford, \\ $\mathrm{OH} 45056$, USA
}

\begin{abstract}
Psychoanalysis is primarily a praxis devoted to curing psychic distress. While human geographers are well acquainted with the theoretical insights of psychoanalysis, there are few spatial analyses of how its theories are put to work in its clinical methods, techniques and practices. The thesis of this paper is that an investigation of the intense spatialities in psychoanalytic sessions can further understandings of psychoanalytic theory and its relevance to critical geographic inquiry. I argue that the transferential forces of play, desire and affect in Donald Winnicott and Jacques Lacan's psychoanalytic treatment of analysands is a realization of, or at least comparable to what Friedrich Nietzsche called a 'gay science'. In proposing a historical precedent to psychoanalysis, I draw on a constellation of meanings associated with the category 'gay' in order to map some spatial nuances of psychoanalytic praxis. The paper focuses on the case studies of Winnicott's 're-mothering' of a male analysand and contemporary Lacanian analyses of hysterics and autistic children. In striving for clinical efficacy, these psychoanalyses utilize, on the one hand, the gaiety of joy, love, desire and mothering, and, on the other hand, the not-so-gay, yet therapeutic, forces of pain, aggressiveness, separation and mourning. The paper concludes by suggesting future directions for gay psycho-spatial analyses through a brief appraisal of the interdisciplinary social theoretical literature of the 'new Lacanians', in particular the work of Slavoj Žižek.
\end{abstract}

Key words: Psychoanalysis, gay, science, Lacan, Nietzsche.

\section{Introduction}

Perhaps laughter will then have formed an alliance with wisdom, perhaps only 'gay science' will then be left. For the present, things are still quite different. For the present, the comedy of existence has not yet 'become conscious' of itself. (Friedrich Nietzsche 1974: 74)

I would very much like to start off this new year, for which I offer you my best wishes, by telling youThe fun is over! (Jacques Lacan 1988a: 7)
'You take care of him,' one father told me, 'You won't mess him up as much as we would. Anyway, I feel fine about coming to see you; I've read that analysts don't talk, and so you won't ask me any questions.' (Catherine Mathelin 1999: 11)

Whenever geographers endorse the theoretical value of psychoanalysis it is customary to issue an advisory that warns of a potentially 'unnecessary, unpleasant experience, just like measles' (Pile 1996: 81). Yet despite this ostensible uneasiness, since the mid-1990s there has 
been a considerable increase in the frequency and intensity of critical engagements by geographers with psychoanalytic theory. Notable contributions have critically evaluated and/or utilized the following approaches: Freudian (Bondi 1998, 1999; Kingsbury and Brunn 2003; Nast 2000; Pile 1996, 1998; Wilton 1998); Irigarayan-Kristevan (Longhurst 2001; Robinson 2000; Rose 1996; Wilton 1998); Lacanian (Blum 1998; Blum and Nast 1996, 2000; Bondi 1997; Doel and Clarke 2002; Gregory 1997; Kingsbury 2003; Rose 1995); object-relations (Sibley 1995); and Winnicottian (Aitken and Herman 1997). These works have prompted the inaugural definition of 'psychoanalysis' in The Dictionary of Human Geography (2000). Gillian Rose (2000: 654), apprises that: 'despite its dangers, psychoanalytic theory is being used by some geographers as a critical tool to reinterpret and reconfigure different kinds of geographies'.

Dangers of psychoanalytic 'universalizing, decorporealized, and culturally decontextualized account [s] of psychosexual development' (Blum and Nast 1996: 571) are well documented. Outside the discipline of geography, for example, critiques have alleged that psychoanalysis enforces patriarchal and masculinist reinscriptions of the 'feminine' into a logic of castration (Irigaray 1985); maintains normative, heterosexist and structurally binaristic epistemologies of gender (Butler 1993); wields repressive understandings of power and subjectivity (Foucault 1988); disavows its geographical and historical biases for predominantly analysing straight Western white bourgeois nuclear families (Brenkman 1993; Derrida 1998); constrains and privatizes the political radicality of desire by foreclosing non-imperialistic 'anoedipal' modes of subjectivity (Deleuze and Guattari 1983); and reduces signification to a phallogocentric logic of supplementarity and lack (Derrida 1987).
Nonetheless, all the authors above acknowledge that their work is infused by an incendiary theoretical capability unique to psychoanalysis theory. It is hardly surprising, then, that Steve Pile should warn that attempts to use psychoanalysis to 'read the relationship between the subject, space, and the social ... must be wary that the letter could be a bomb' (1996: 8).

This paper attempts to initialize new dialogues between psychoanalytic and critical geographic inquiry through a strategy that involves not so much the traditional method of reading psychoanalytic texts and arguing for the suitability of concepts that can be readily applied to interpret concrete everyday psycho-spatial phenomena. Instead, I aim to illustrate how psychoanalysis can be also understood as a critical and even subversive clinical praxis grounded in the intense psycho-spatial dynamics of 'two subjects linked by a pact' (Lacan 1988a: 181) who desire through a dialectics of healing to cure psychic distress (cf. Bondi 1999). In the name of paid-for non-altruistic transferential love, psychoanalysis sanctions radical intersubjective relations that combat suffering by giving 'birth' to renewed subjects via the curative and spatializing forces of play, affect and creativity. ${ }^{1}$ By critically investigating why and how (overdetermined) psychoanalytic techniques, methods and theories are spatially called forth and actively 'put to task' (Rose 2002: 462) in analysis, then questions about relationships between critical psychoanalytic and geographic inquiry become more vital. In addition, doubts and desires of 'getting from' abstract clinical psychoanalytic praxes to the ground of 'doing' psychoanalytically informed critical geographic inquiry can only begin through patient reading and writing (cf. Strohmayer 1997: 177). I desire, then, to convey how psychoanalytic praxis problematizes polarized and territorializing expeditions from the 
structural realms of the 'abstract' to the 'concrete'.

Doing justice to the value of psychoanalytic approaches for geographies 'beyond the couch' requires not only comprehending why 'psychoanalysis is, after all, a spatial discipline' (Pile 1996: 77), but also how psychoanalysis is a praxis capable of mobilizing and being mobilized by space. While some geographers reject psychoanalytic theory outright because of the perceived dangers diagnosed above, perhaps a greater number of geographers are simply skeptical or unsure of how psychoanalytic theory can add anything new to existing critical methodologies and explanations of geographic phenomena. Pile (1998) has suggested most geographers assume that the unconscious is static and that psychoanalysis is excessively concerned with the person(al) and thus unable to inform critical analyses of social power relations. Dangerous 'decontextualizing' accounts of psychoanalytic theory that are prone to wield heteronormative and two-dimensional understandings of space (Blum and Nast 1996, 2000) are comparable to the dangers of failing to theorize or contextualize psychoanalytic theory vis-à-vis its multifarious concrete praxes. There is also an overdetermined geography to be written on the political, historical, cultural, linguistic and economic dimensions that contribute to the knowledge production, uses and perceived efficacy of psychoanalysis in particular times and places, such as Nazi Germany (Rickels 2002), ecology in 1920s England (Cameron 2001), post-colonial Argentina (Plotkin 2002) and 'the rest of the world' (Derrida 1998). ${ }^{2}$

Psychoanalysis, I argue, is in many ways a realization of, or at least comparable to Friedrich Nietzsche's notion of a 'Gay Science' (Die Fröhliche Wissenschaft), the title of one of his most beautiful and important books. A gay science is a critical form of scientific scholar- ship that was 'superficial-out of profundity' (Nietzsche 1974: 38) with a stinging alliance of laughter and wisdom (see epigraph). ${ }^{3}$ In suggesting a historical precedent-an urphenomenon of psychoanalysis-this paper plays with more contemporary and alternative connotations of the category 'gay' (joyful, male, vivid, incessant, animated, charming, insouciant, sugary, cheerful and funny) and notso-gay meanings (offensive, cold, anxious, abandoned, routine, negative, painful, aggressive and mournful) in order to tease out queer dimensions of psychoanalysis. By queer, I refer, on the one hand, to aspects of psychoanalytic theory, methodology and praxis that reject any universalizing, pathologizing and regulatory tendencies underpinned by a metaphysical faith in pure and fully present heterosexual or 'normal' desires, identities and identifications (Dean 2000; Verhaeghe 2001). On the other hand, I seek to queer a supposedly straight monolithic psychoanalysis by mapping the 'open mesh of possibilities, gaps, overlaps, dissonances and resonances, lapses and excesses of meaning' (Sedgwick quoted in Dean 2000: 234) grounded in the rattle and hum of desirous clinical praxes with hysteric and autistic analysands. The consequences of queering psychoanalytic desire that 'crawls, slips, escapes like the ferret' (Lacan 1977b: 214) is becoming for geographers because it furthers our understandings of the production and seduction of spaces that teem in concrete clinical contexts enabling new psychoanalytic understandings of sexuality and space. $^{4}$

The paper is organized as follows: First, I discuss Nietzsche's gay science and how it prefigured Sigmund Freud's early 'project for a scientific psychology' that eventually crystallized into 'psychoanalysis'. Second, I use the example of Donald Winnicott's analysis of Harry Guntrip to show how a 'holding environment' or clinical space where '[t]rans- 
ference-is love' (Lacan 1988a: 90) permits the gay-joyful transferential and empathic gaymale ways of loving qua mothering that gives birth to new subjectivities. Third, while critical of Winnicott's object-relations theory, the success of Lacanian psychoanalysis is nonetheless similarly determined by the analyst's gayanimated strategies to elicit desire in and release the analysand from the suffering of their symptom to enable them to 'traverse the fantasy' (la traversée du fantasme - the Lacanian version of Sigmund Freud's 'working through'). ${ }^{5}$ Fourth, by focusing on the Lacanian psychoanalytic treatment of autistic children and hysterics where 'the subject is freed of the obligation, not only to be polite, to be courteous, but even to be coherent' (Lacan 1988a: 181), we can map a constellation of the not-sogay charm offensives that co-ordinate psychoanalytic efficacy. Lacanian psychoanalysis endeavours to unhinge the analysand's subjective consistency through a 'sort of psychological catastrophe' (Lacan 1988a: 112). This psychic state is born(e) out in spaces of hatred, sadness, aggression, and trauma during transference or 'the enactment of the reality of the unconscious' (Lacan 1977b: 146) in languagethe 'big Other'. Finally, my paper concludes with a brief appraisal of a now significant body of inter-disciplinary literature by the 'new Lacanians' (Mellard 1998), in particular, the work of Slavoj Žižek to provide 'signposts' (Natter and Jones 1993) toward future critical psychospatial analyses.

Now, this paper is not preoccupied with evaluating the extent to which psychoanalysis is gay, scientific, spatial, or even a gay spatial science. ${ }^{6}$ Instead, this paper prefers to heed the category 'gay' in its various connotations to navigate the spatialities of the clinical praxes between and within two psychoanalytical 'schools'. In so doing, this paper desires to overcome acutely grafting notions of 'danger', or 'measles', complicit with a fantasy or 'group fantasy' (Deleuze and Guattari 1983: 30) of a venerable, vulnerable and sometimes feared Other dubbed 'psychoanalysis'. In recalling The Dictionary of Human Geography's tentative definition, this paper takes very seriously the propensity for gay psychoanalytic inquiry to not only reinterpret and reconfigure different kinds of geographies, but also to re-evaluate psychoanalytic geography itself.

\section{Beyond the spirit of gravity}

Given Nietzsche's immense influence on Critical Theory, the 'Frankfurt School', French 'poststructuralism', and feminism (see, e.g., Benjamin 1977; Deleuze 1983; Derrida 1981; Foucault 1980; Irigaray 1991; Lefebvre 1991), which together delivered human geography's 'cultural', 'linguistic' and 'postmodern' turns, it is surprising that geographers have rarely written more than a paragraph or two in discussions of Nietzsche's work (see, e.g., Barnes 1996; Doel 1999; Gregory 1994; Nemeth 1997; but see Kingsbury 1999). Nietzsche's project of re-evaluating Western philosophy also anticipated the goals, tenets and spirit of Freudian psychoanalysis (see, e.g., Assoun 2001; Chapelle 1993; Lehrer 1995; Wolfenstein 2000). In 1925, Freud admitted that he refused to read Nietzsche's work, fearing that its radicality would de-rail his precarious intellectual development and treasured psychoanalytic project (see Assoun 2001: 5). ${ }^{7}$

Opposed to the Victorian 'antlike' drudgery of amassing facts, Nietzsche's book The Gay Science (originally published in 1882) proposed an innovative form of scholarship that would be light-hearted, creative, experimental and, above all, defiant of the repressive 'spirit of gravity' that burdened conventional scientific and academic practices. ${ }^{8}$ Nietzsche, a 'psychol- 
ogist of knowledge' (Kaufman 1978) contended that we

are not thinking frogs, nor objectifying and registering mechanisms with their innards removed: constantly, we have to give birth to our thoughts out of our pain and, like mothers, endow them with all we have of blood, heart, fire, pleasure, passion, agony, conscience, fate, and catastrophe. (Nietzsche 1974: $35-36)$

Nietzsche believed that the scandal of nineteenth-century European academic scholarship [Wissenschaft] lay in its assumption that disciplined, serious and rigorous science (important qualities nonetheless for Nietzsche) could only coincide with 'stodgy, heavy, dusty, or, in one word, Teutonic' ways of thinking (Nietzsche 1974: 5). Nietzsche's gay science opposes neat equations of reason, emancipation and progress, and is an anti-Enlightenment philosophy par excellence (see also Foucault 1984; Horkheimer and Adorno 1976).

Nietzsche's gay science rallied for the conscious re-evaluation of scientific values (see epigraph) and prefigured Freud's re-evaluation of subjectivity and sexuality by making unconscious knowledge speak through the introduction of radical 'scientific' methods such as free association. Nietzsche's gay science and Freudian psychoanalysis share many fundamental conceptual tenets. For example, the individual's quest for (self) knowledge typically encounters a sickness of the soul or psyche; instinct for life is intimately linked with death; knowledge is perspectival, embodied and willed; consciousness is merely one part of woken life; and the belief that human condition could be improved by overcoming the decadent inhibitions attributed to a Judaeo-Christian morality of shame that imbued European civilization. Nietzsche prescribes the gay science as an antidote to the allegedly European cultural and spiritual sicknesses of modernity exem- plified by Socratism, Romanticism and Christianity:

In the end, lest what is most important remain unsaid: from such abysses, from such severe sickness, also from the sickness of severe suspicion, one returns newborn, having shed one's skin, more ticklish and malicious, with a more delicate taste for joy, with a tenderer tongue for all good things, with merrier senses, with a dangerous innocence in joy, more childlike and yet a hundred times subtler than one has ever been before. (Nietzsche 1974: 37)

The gay science, then, facilitates the re-birth of life and living. Children are praised throughout The Gay Science because Nietzsche believed that a child's life was saturated with spontaneous and creative energies. In one aphorism, Nietzsche warns that envious people should not have children, because they would grow even more envious, no longer able to be a child. If in 1784, Immanuel Kant defined Enlightenment [Aufklarung] by bidding his readers to cast off their chains of immature tutelage, a century later, Nietzsche urged gay scientists to heed a 'will to truth' as an infantile pursuit (cf. Žižek 1997: 78). The gay science was eventually desired through the birthing of an epistemological renaissance through a male mother, Nietzsche's prophetic character and mythic alter ego Zarathustra, who destabilizes prosaic masculine ways of systemic thinking through struggles with the redemptive ecstasies of a 'feminine' will to power (Picart 1999).

\section{The will to flower and remaining true to the earth}

Written between the years of 1883 and 1885 , Nietzsche's sequel, Thus Spoke Zarathustra: A Book for All and None (his most 'fictional' and enigmatic work) portrays the iconoclastic sage Zarathustra-the incarnation of a gay scientist. 
Zarathustra teaches the doctrine of 'eternal recurrence', grapples with nihilism, and divines the future through metamorphoses of a camel, lion and a playful child. The child is a metaphor for Nietzsche's notion of the Übermensch or Overman, an ideal (inspired by Hellenism), for humanity to 'overcome' itself by attending to the world's power in the 'here-and-now' rather than deferring life for a dubious heavenly world of redemption:

Let your will say: The Overman shall be the meaning of the earth! I conjure you, my brethren, remain true to the earth, and do not believe those who speak to you about otherworldly hopes! (Nietzsche 1999: 3, translation modified)

Zarathustra dances like a chimera amidst polyphonous and multiple subjectivities that attempt to 'remain true to the earth' by revelling in gay-queer abandon. Refusing to be fixed by normative categories of 'masculine' or 'feminine', Zarathustra recalls the Greek patrilineal birthing myth of Dionysus, Zeus and Apollo. For Zarathustra, only the self-regenerative experience of giving birth to Übermenschen can grant access to the will-to-life in all its inexhaustability and indestructibility. Unfortunately, Zarathustra (an immaculate male virgin) gives birth to monstrous warrior-heirs ('higher men') that cannot meet his ideals and are sacrificed in battle for the coming of the Übermensch.

In Resentment and the 'Feminine' in Nietzsche's Politico Aesthetics (1999), Joan Picart argues that Nietzsche belabours the creation of a philosophy free of resentment through the self-generative births of his 'mythic alter ego' Zarathustra. Creatively impotent, and thus unable to give birth to the Übermensch, or indeed, the 'over-Nietzsche' (Salomé quoted in Picart 1999: 98), Nietzsche's philosophy of becoming is shackled by a haunting resentment that succumbs to the shrill denigration of 'woman' and hardens into a deep-seated misogyny in later books. Similarly, Luce Irigaray's Marine Lover of Friedrich Nietzsche (1991) argues that Nietzsche suffers from 'womb-envy', longing to be a mother, re-birth his self and return to the womb. Eleven years before his death, Nietzsche's resentment ended in an infamous descent into 'insanity' which, had it existed, psychoanalysis may have been able to alleviate (cf. Yalom 1993). ${ }^{9}$ Unlike Nietzsche or Zarathustra's impotence to birth 'healthy' revitalized subjects, Donald Winnicott was a mother who could psychoanalytically utilize the healing powers of creativity and spontaneity to re-mother his analysands in the holding' space of analysis. Winnicott conceptualized suffering as symptomatic of a failure to play and create adequately. It is to the spatiality of Winnicott's psychoanalytical praxis that I now turn.

\section{Insults of the reality principle}

Influenced by British scientific empiricism and seeking to avoid theoretical excesses, Winnicott believed psychoanalysis could illuminate laws that governed seemingly irrational phenomena. Early in his career, Winnicott became frustrated with the discipline of physiology because it was 'cold' and complicit with not-so-gay strategies that sought 'to eliminate variables such as emotion' (Davis and Wallbridge 1981: 12). As a newly qualified paediatrician, Winnicott was deeply inspired by the work of Freud but eventually rejected Freud's theorization of aggressiveness as a function of the death drive. Winnicott argued that impulses and drives were primarily the effect of spontaneity and creativity. For Winnicott, threats to psychic wellbeing were generated by environmental failure that blocked productive engagements between 
the individual and society. In a study of the 'anti-social character', Winnicott argued that stealing was a creative form of communication, a creative hope that reflected the analysand's unconscious feelings that they once had their parents' love and felt the right to have it returned (Winnicott 1984). For Winnicott, 'life was worth living' (Davis and Wallbridge 1981: 5) and a struggle against the 'insult of the reality principle' that stymied creativity (Winnicott 1971). Echoing Nietzsche, Winnicott wagered that the basis for humanity's experiential existence could be attained through the modalities of creativity and play (Winnicott 1971).

In 'Gender, power and crib geography: transitional spaces and potential places' (1997), Stuart Aitken and Thomas Herman argue that Winnicott's concept of a 'transitional space' (echoing Nietzsche's gay science) relies on the importance of 'frivolity, intuition, emotion' (1997: 64) and contributes to postEnlightenment thinking and masculinist forms of reason by refusing to fixate on specific values and meanings. Rather than examine Aitken and Herman's pertinent claim that 'Winnicott may be complicit with a patriarchal idealization of child development' (1997: 82), I focus on the analyst Harry Guntrip's personal recollections of some 150 sessions he went through as an analysand with Winnicott in the 1960s. Here, one encounters Winnicott's 'potential space' of a gay-queer science qua the analytic 'intimacy of the confidential couple' (Althusser 2001: 136).

\section{Straining, listening and holding Harry Guntrip}

Winnicott believed that the mother's unique capacity to identify with the baby enabled her to act as an ego support during the infant's initial stage of absolute dependence. According to Winnicott, the baby and the mother were a thoroughly entwined psychic-somatic space where there was 'no such thing as a baby' (see Davis and Wallbridge 1981). In contrast to Freud's reluctance to identify with a maternal postionality during analytic sessions, Winnicott embraced the place of the Imaginary good (enough) mother. ${ }^{10}$ Through this Imaginary identification with the analyst/mother's care, Winnicott's analysands were able to benefit from intersubjective creativity. Winnicott contended that the efficacy of analyses depended on the analyst's ability to adopt the creative healing powers of good mothering. This Imaginary relationship precipitated intense circulations of affect that Winnicott negotiated through the frame of a 'holding environment', a combination of psychological and physical space.

In 'My experience of analysis and Fairbairn and Winnicott (How complete a result does psycho-analytic therapy achieve?)' (1986), Harry Guntrip compares the formal, conservative and intellectually austere psychoanalytic practices of Ronald Fairbairn to Winnicott's more revolutionary practices (1986: 450). Guntrip observes that, rather than foster an analytic space of austere neutrality, the gay-cheerful 'tea-sipping' Winnicott invested in the material gaiety of colour and comfortable furniture. Guntrip notes that he was able to sit sideways or lie down on the couch in Winnicott's

consulting room [that] was simple, restful in colours and furniture, unostentatious, carefully planned, so Mrs. Winnicott told me, by both of them, to make the patient feel at ease. (Guntrip 1986: 454)

Underpinned by an object-relations theory, the ontology of Winicott's analytical space objectively consists of a couch qua mother and pillows qua breasts. With this 'facilitating environment' Winnicott could creatively re- 
mother and re-conceive analysands through regression and thus relieve them from debilitating unconscious traumas. Winnicott aimed to become a 'good breast' for the infant-self in Guntrip's unconscious. Guntrip recalls Winnicott's words:

It's like you giving birth to a baby with my help. You gave me half an hour of concentrated talk, rich in content. I felt strained in listening and holding the situation for you. You had to know that I could stand your talking hard at me and my not being destroyed. I had to stand it while you were in labour being creative, not destructive, producing something rich in content... You too have a good breast. You've always been able to give more than take. I'm good for you but you're good for me. Doing your analysis is almost the most reassuring thing that happens to me. The chap before you makes me feel I'm no good at all. You don't have to be good for me. I don't need it and can cope without it, but in fact you are good for me. (Guntrip 1986: 461-462)

The violent bouts of concentrated talk result from Guntrip's extreme discomfort of silence in analytical sessions. Winnicott urges Guntrip to confront silence so that a form of intrapsychic dependence can ensue. Guntrip demands from Winnicott maternal love, but this is never displaced into actions because it would arrest the therapeutic effects of speech and thought. Winnicott must always remain in the place of the Imaginary mother by never realizing the corporeal embodiment of maternal authority as the 'true answer' to Guntrip's 'problems'. Winnicott's analysis aims to precipitate Guntrip's discovery of his own 'good breast' and ability to caress himself psychically. Winnicott's object-relations theory regards anxiety as the retroactive effect of a repressed feeling of a deficit or loss of an 'object' exemplified by the mother or primary care taker. Re-mothering, then, involves the re-living of intense not-so- gay feelings of anxiety and abandonment. As Winnicott remarks to Guntrip:

You began to feel afraid I'd abandoned you. You feel silence is abandonment. The gap is not you forgetting your mother, but mother forgetting you, and now you've relived it with me. You're finding an earlier trauma which you might never recover without the help of ... [a previous] trauma. You have to remember mother abandoning you by transference on to me. (Guntrip 1986: 461)

Winnicott's 'imaginative hypotheses' (Guntrip 1986: 466) combine caring and daring under the aegis of male motherly love. The gay-queer transferential love, sanctioned by psychoanalysis, eventually appeased Guntrip's trauma. Winnicott's psychoanalytic praxis, then, mobilizes a gay-queer science not simply because of Winnicott's Imaginary identifications qua mother but also the radical dissemination of subjectivity that undermines any fixed or normative understandings of space, sex, gender and sexuality. Analytic healing takes place through the analyst and analysand's dialectical pact of loving borne out of the transferential passions of intersubjective speech. Jacques Lacan, however, argued that Wincottian praxis was not-so-gay because it promoted the narcissistic love of similarity and wholeness between two identifying egos caught in the mirrored misrecognition of Imaginary space and transference. It is to the Lacanian anamorphic spacing of punctuation, interruption and scansion that privileges enigmatic desire over maternal love that I now turn.

\section{Some kinda love: the Lacanian analyst's enigmatic desire}

Lacanian psychoanalysis is often compared to object-relations theory because they share an 
emphasis on 'intersubjectivity' during analysis (Evans 1996). ${ }^{11}$ Lacan, however, criticizes object-relations theory primarily because it idealizes a complementary and completely satisfying relationship that 'conjoins to a need an object which satisfies it' (Lacan 1988a: 209) where there 'is a direct stitching together of desires, which dovetail together, bind together' and 'discordances, gaps are only accidental' (Lacan 1988a: 211). From a Lacanian perspective, object-relations theory situates objects in the biological register of need, thus neglecting the Symbolic dimension of desire. ${ }^{12}$ In the space of the Lacanian analytic session, desire is the 'driving force', and the analysand's desire (although suffocated) must come to the fore. ${ }^{13}$ In many cases, people go into analysis because their desire is stuck, or they are libidinally petrified. As Fink (1997) notes, for Lacan, human desire (unlike demand) has no specific object because desire is not

drawn toward an object (Desire $\rightarrow$ Cause) as elicited by a certain characteristic [e.g. a certain timbre of the voice, the way a person looks at you] that can sometimes be read into a particular love object: desire is pushed not pulled (Cause $\rightarrow$ Desire). (1997: 51)

According to Lacan, psychoanalytic praxis is concerned not so much with the reliving of past experiences through the abreaction of affect as it is with the articulation in speech of the truth about unconscious desire (Evans 1996). The Lacanian analyst must avoid sessions that are either too 'affective smoochy-woochy' (Lacan 1988a: 55) or too 'intellectual' (Lacan 1988a: 274). For Lacan, affect is a potential lure that could deceive the analyst and it is imperative to make careful use of it. The analyst must occupy the place of radical alterity (the place of the 'big Other') by becoming the analysand's cause of desire (in Lacanese the 'objet petit $a$ '), and trigger spoken unconscious formations. ${ }^{14}$ Instead of 'spoon-feeding meaning' (Fink 1997: 45) the analyst fosters a space of alienation and arouses the analysand's unconscious through polyvalent 'oracular ... interpretative interventions' (Lacan 1977a: 13).

For Lacan, the 'analyst's desire' is not a Winnicottian maternal counter-transferential desire for the analysand to recover. This is partly because 'the analyst's position is exactly the inverse of the mother's position, he is not at the foot of the bed, but behind, and he is a long way from offering, at least in most instances, the charms of the primary object' (Lacan 1988a: 242). In a Lacanian session, desire is expressed in 'oracular speech' to emphasize manifestations of the unconscious (Fink 1997: 6). Enigmatic and purified, the analyst, then, is no longer an-other person but a more abstract Other person (under erasure [sous rature]) that speaks in the spaces of the slips, cracks and ambiguities of the analysand's discourse (cf. Doel 1999: 109). In contrast to Winnicott, the Lacanian analyst is devoid of a character or personality (Fink 1997: 31). Their 'impersonal desire' (Dean 2000) is devoted solely to the work of analysis specific to their function, role or part to be played as an analyst in the position of the 'big Other' and the objet petit a (see, e.g., Lacan 2002: 306). ${ }^{15}$ Here, Lacanian 'objects' such as the 'big Other' or the analyst are not 'things' with intrinsic qualities, but rather embodiments of a position or place whereby 'the place logically precedes objects which occupy it' (Žižek 1989: 194). Theorizing space whereby the impersonality of objects are privileged over the qualities of personal identity allows us to theorize sexuality 'outside the realm of individuals - indeed, outside the realm of persons' (Dean 2000: 17) and pursue gay pycho-spatial analyses. The radical implication of this understanding of sexuality and space is the sine qua non of Lacanian praxis. 


\section{Toward the Archimedan point of analysis}

Lacanian analytic sessions take place through the anamorphosis of desire, 'bent like space in the theory of relativity' (Žižek 1999b: 155), where desire is a meandering question. Once the analysand engages in the undecideability of the words they speak, that is, asks themselves why they say certain things, 'or even who was speaking when they opened their mouth' (Fink 1997: 25), then their desire is properly engaged in analysis. The analysand can own up to their unconscious that gaily-vividly speaks through them and begin to wonder and wander about words and fantasies. This moment signals the analysand's true entry into analysis (Fink 1997: 26), a shift into what Lacan calls the 'dialectic of desire' (Lacan 2002). This means that the analysand exchanges repetitive demands for a cure, approval, recognition, that is, love, for the gay-incessant movement and variability of desire (see Fink 1997: 26).

Such strategies are directed towards what Lacan calls the 'Archimedean point of analysis' (Fink 1997: 39), a position or occasion where the analyst can lever and move the detrimental symptom that blocks the analysand's desire. The Archimedan point can be reached through the analyst's unflagging desire 'for the patient to talk, dream, fantasize, associate, and interpret' (Fink 1997: 5). For Lacan, the analyst's desire enables the analysand to overcome their jouissance, or 'getting off' on the 'passion for ignorance' as the will to ignore (ne rien vouloir savoir) their neurotic symptom (see, e.g., Lacan 1988a: 271). ${ }^{16}$ Desire enables the analysand to overcome neuroses configured in unsustainable defence formations (e.g. obsessional, phobic or hysteric) and to begin to formulate a new kind of subjective knowledge. To do this, it is imperative to encourage the analysand to say anything that comes to mind without censorship. This can be thwarted, however, if the analysand awaits the brilliant formulation from the analyst endowed with the function of 'the subject supposed/presumed to know' (sujet supposé savoir), an authority-figure 'in the know'. Analysands often seek to impress and therefore risk internalizing prohibitions that could restrict speech and dissipate transferential dynamics. The constant seeking of approval is a neurotic strategy par excellence that binds the analysand ever closer to the Other's opinion (see Fink 1997: 37). The true subject supposed to know, of course, is the analysand's unconscious, the ultimate authority that should be projected on to the analyst.

\section{Traversing the fantasy}

Analysis, then, is a space that involves the 'process of fleecing, of peeling away the systems of defense' (Lacan 1988a: 185) requiring the analyst to make gay-animate the analysand's stymied desire. This process operates in the differential spaces of spoken signifiers and silence whereby the Lacanian analyst uses strategies to query, intervene, upset and generate new meanings in the analysand's discourse. The technique of punctuation (ponctuation) involves unexpected silences, repetitions and interruptions of the analysand's speech to emphasize the manifestations of the unconscious by 'showing the subject that he is saying more than he thinks he is' (Lacan 1988a: 54). Punctuation prompts the analysand to engage in deciphering the animation of their unconscious. Another form of punctuation, scansion, comprises the (controversial) Lacanian practice of 'short' or 'variable duration sessions' (séances scandées) (see Schneiderman 1983: 132-156). A sudden interruption and non-verbal accentuation of the session occurs at a particular moment that the analyst deems to be of particular 
significance, such as the manifestation of unconscious desire. 'Scanding' a session can prevent the stultifying effects of not-so-gay routine sessions and unnecessary chatter or 'empty speech' that detracts from desiring utterances. Scanding also maintains an element of surprise that keeps the analysand off-guard and stops the analysand (especially the obsessivecompulsive) from procrastinating or executing a series of responses planned before a session (Fink 1997).

Lacanian analysis, then, invests in the above techniques that realize the transformative and healing capacities of unconscious space through its gay-insouciant or restless power to reanimate stuck or fixated desire. Once desire has been 'dialecticized', that is, when the analysand confronts the contradictions and ruptures in their speech, the analyst's enigmatic desire (the Other's desire) aims to bring about a radical calling into question of the analysand's interpretation of the Other's demands configured in their fixated unconscious 'fundamental fantasy' and 'introduce a certain distance retroactively' (Fink 1997: 65). By 'traversing the fantasy', the analysand surrenders the stubborn certainty of being subject to the Other's demand and experiences how the fantasy object (l'objet petit a) 'only [retroactively] materializes the void of our desire' (Žižek 1989: 65). When the analysand assumes a new position vis-à-vis the Other as language and desire, she or he can then modify their fundamental mode of defence and specific organization of jouissance that have hitherto subjugated their desire. The analyst's desire allows the analysand to decrease their anxiety and finally 'enjoy enjoyment' to the extent that they are no longer in the stranglehold of the Other's enigmatic desire.

Forms of 'transference love' experienced early in the analysis often give way to less-gay forces. This happens because the analyst is attributed as the cause of the analysand's un- conscious formations. An analysand may feel subjected to a space where the analyst is 'getting under their skin' or becoming too intrusive in their lives (Fink 1997: 39). The spatial operations of psychoanalytical praxis as a refined 'cruel method of humiliation' (Žižek 1991b: 156) qua its not-so-gay psychical forces have been addressed at length by analysts in two books: Catherine Mathelin's Lacanian Psychotherapy with Children: The Broken Piano (1999) and Juan-David Nasio's Hysteria from Freud to Lacan: The Splendid Child of Psychoanalysis (1998).

\section{Autistic children, perilous pleasure, diamond bodies}

In the editorial introductions to the Lacanian Clinical Series, Judith Guerwich argues that academics removed from a clinical context have failed to understand Lacan's teachings as primarily a praxis devoted to cure psychic distress (see also Felman 1987: 154-159). The series is the first English translation of contemporary clinical practices of Lacanian psychoanalysts based in France (Kingsbury 2001). Written by Paris's leading child analyst, Catherine Mathelin, Lacanian Psychotherapy with Children: The Broken Piano (1999) is a powerful answer to academic claims that Lacan's writings are too obscure, phallogocentric, patriarchal or reactionary. Mathelin's book consists of fourteen cases that depict the distress of (mostly autistic) children whose crippling pain is a symptomatic 'lie' of the imposing silences in unresolved parental conflict. Mathelin notes that children usually express greater intensities of hatred than adults, and demonstrates the analyst's healing powers configured in listening and talking about pictures drawn by the children. In the past decade, French hospitals have become in- 
creasingly dependent on the services of psychoanalysts. The analyst on a neonatal unit can offer 'a heart the wish to live, while the doctors are forcing the heart that is a piece of meat to continue to beat' (Dolto quoted in Mathelin 1999: 169). In offering a heart, the analyst provides a space for children and parents to examine illness, confront desire and 'risk' envisioning a different life. In asserting the gay re-creativity of analysts, Mathelin argues they must remain alert, creative and ready to be unsettled, aware that 'each child has his own theory, and it is from him that we get it' (Mathelin 1999: 18). In the case of 'Félicien and the 'intellectual women', Félicien

finally found a space in which he was allowed to express his horror... In no case is it a matter of sugary generosity and devoted good will, but instead of the transference at its most violent. (Mathelin 1999: 23-24)

The importance of the not-so-gay or not-sosugary dimensions of analysis is illustrated in Hysteria from Freud to Lacan: The Splendid Child of Psychoanalysis (1998), where JuanDavid Nasio argues that psychoanalysis can be simply understood as the 'artificial setting up of hysterical neurosis and its final resolution' (Nasio 1998: xxi). Here, analytic space generates aggressiveness that form not-so-gay 'negative transference that is the inaugural knot of the analytic drama' (Lacan 2002: 16) so that psychical resistance can be lessened and conflicts worked through. Hysteria (like all neuroses) is 'an inadequate way of defending ourselves, the inappropriate means that we unknowingly employ to confront an unconscious and dangerous pleasure' (Nasio 1998: 11). Nasio writes that hysteria is not an illness centred around or in the discrete space of an individual but the unhealthy space of a human relationship. Hysteria expresses the ties and bonds a neurotic fantasmatically weaves and unravels in relations with other people.

Nasio maps three components of the ego that comprise hysteria and can be observed during transference. First, the 'unsatisfied ego' passively aims to reduce anxiety by securing an unremitting state of dissatisfaction. This is a defence that avoids the danger of a dreaded pleasure (jouissance) of absolute fulfillment that would make the hysteric go 'crazy' and 'dissolve'. 'Playing the role' of a perpetually unsatisfied victim, the hysteric unconsciously creates the 'fantasy of a monster whom we call the other' (Nasio 1998: 5). This other, configured in friends, loved ones and the analyst, oscillates between being all-powerful and weak, but is always ubiquitous, immense and disappointing. The acutely perceptive hysteric seeks and always finds signs in the other's desire, a humiliating strength or touching weakness that moves the hysteric to pity and powerlessness. Discontentment is the hysteric's preferred 'guardian' (see Nasio 1998: 6).

The second state, the 'hystericizing ego', transforms the space of daily life and the analysis into a sexualized fantasy. To hystericize is to arouse in the other's body a furnace of libido' (Nasio 1998: 7) that transforms gestures, looks, silences and material objects into erotic signs. Eliciting desire and promising a sexual relation, these signs always remain unrealized to maintain the neurotic's state of nonsatisfaction. For Nasio, the hysteric's ego spatially assembles the body like the pattern of a harlequin costume. Diamond shapes correspond to distorted images of limbs, organs, orifices and other parts of the body that get detached during encounters with trauma. Hysteria, as a conscious suffering in the body, is the conversion (a failed repression) of unconscious and unbearable pleasure into somatic distress. Furthermore, the hysteric's coconstitutive libidinal economic geographies of 
body and world (what Lacan calls the 'being of the organism') are remarkably elastic and stretched across space while articulated in the spoken space of analysis (cf. Lyotard 1993; Massey 1994). In the words of one of Nasio's female analysands:

Every time I hear the click on the main door to the building, when you open it for me by pressing your finger on the intercom button, I feel your finger pressing against the skin of my arms... I imagine what's going on in you as though I were your own skin all around you. I feel your movements in my skin because I'm your skin ... It's reassuring to think that, and to tell you about it, and it gives me a boundary. It's the reasoning that's the boundary. (Nasio 1998: 9, emphasis added)

In the third state, the 'sadness ego', the hysteric can gaily identify with a man, woman or the fault-lines between the members of a couple, and embody the discontent that causes the couple distress. The hysteric invariably identifies with the exclusion. Emptied of a sexual identity, the hysteric from a Lacanian perspective is 'no longer a man, no longer a woman' but 'the pain of dissatisfaction' (Nasio 1998: 10). Again, such a theorization of sexuality belies the gay-queer elements of a Lacanian conceptualization of space and sexuality.

What spaces are involved when Nasio analyzes the torment and sadness of the hysteric? In addition to the reassurance of speaking about the experience, Nasio describes how the analyst's 'visual listening' during transferential speech integrates what the hysteric represses and isolates. The analyst 'looks at what the patient desires' (Nasio 1998: 73) and aims to 'distribute this excess [jouissance] into a multiplicity of representations, to collectivize the excess-in short, to defuse it by dispersing it' (Nasio 1998: 23). The analyst identifies with the inassimilable excess-the somatic and psychical suffering, and becomes the energy itself, achieved not through theory outlined in books or a 'correct' interpretation, but by embedding oneself in the psychic core of the excess. The analyst 'grafts desire' on to the hysteric's exhausted ego and through receptive listening embodies the analysand's 'nucleus of suffering' (Nasio 1998: 25). Listening confers Symbolic meaning and 'kills' the symptom through the progressive 'draining away' (Miller quoted in Fink 1997: 49) of the Real into the Symbolic, thus transforming the passionate attachment to the symptom into something ordinary and banal, in short, a 'gift of shit' (Lacan 1977b: 268). ${ }^{17}$ For Nasio, visual listening requires that the analyst must not wonder how to intervene or what to say, but rather, what to fantasize. This allows the analysand to traverse the fantasy sometimes referred to as 'getting beyond the level of identification' or 'passing through the ordeal of anxiety' (Nasio 1998). The process is at once magnificent and spatial:

I, for one, would imagine it as follows: approaching the anxiety slowly until it is as close as possible, containing it in its greatest tension, and crossing through it. Crossing it as one steps through the frame of a doorway that, at the very instant of the crossing, narrows into a thin, sharp blade that passes right through the body, leaving there the umbilical trace of a transparent slit. Traversing anxiety means being traversed by it. (Nasio 1998: 88)

For Nasio, traversing the fantasy, an onerous 'coming into being of the analysand as subject' (Nasio 1998: 97), is like a realization of Freud's celebrated maxim 'Wo Es war, soll Ich werden', usually translated by Lacan as 'where that was, I must come to be'. According to Nasio, passing through anxiety (detaching from the fictive Symbolic Other) leads to a final phase of serene sadness characterized by the not-so-gay 'pain of mourning'. Here, Nasio echoes Lacan's conceptualization of the ending of analysis as a time of 'subjective destitution' and separation 
(la désêrtre) from the analyst. Nasio argues that once the analysand has worked through their mourning, the analysand can finally embrace a 'post analytic' period with an 'unconscious plus the experience of the unconscious' (Nasio 1998: 102) that is able to perform 'unconscious self perception', or what Freud called 'endopsychic perception'. ${ }^{18}$

\section{The non-dupes err: psychoanalysis is not what you think, it is ... ? ${ }^{19}$}

The closing section of this paper takes its name from one of Lacan's unpublished seminars, Les Non-Dupes Errent delivered between 1973 and 1974, a homophony of the formulations the 'Name-of-the-Father' (Nom-du-Père) and the 'No-of-the-Father' (le 'non' du Père). In erring, in 'writing awry' (cf. Žižek 1991b) through a meandering queer desire named gaiety, this paper encounters the theoretical and clinical complexities of psychoanalytic praxis. To err is to become suspicious and 'queery' any morbid temptation to hastily erect a single body of knowledge called 'psychoanalysis'. To unilaterally arrest, refuse and deny a becoming gaiety specific to psychoanalysis flirts with flatly becoming a straight-out dupe. Given the complexity and scope of psychoanalytic literature, psychoanalysts and their works travel like packs of wolves and there are thousands of entry points into their writings (cf. Deleuze and Guattari 1987: 12, 28). There is never just one Lacan or Freud (cf. Doel 1999: 156) and psychoanalysis is neither 'a Weltanschauung [a totalized or totalizing world view], nor a philosophy that claims to provide the key to the universe' (Lacan 1998: 77).

By addressing a panoply of spaces that include Zarathustra's metamorphoses, Winnicott's male to male motherly love amidst restful colours and furniture, Lacan's fostered alien- ation, oracular and anamorphic desire, Archimedan points, traversals of fantasy, autistic expressions of horror, and hysterical diamond bodies that stretch out a libidinal economy betwixt loved ones, fingers, buttons and skin, analytic spaces-praxes are not merely abstract but concretized in lived clinical spaces qua swarms of gay and not-so-gay forces. The intensity of analytic space is such that Lacan evoking the 'technique of Zen' (1988a: 1) can logically claim that psychoanalysis proceeds not only when the gaiety-fun is over (see epigraph) but also continues by becoming gayfunny: 'The closer we get to psychoanalysis being funny the more it is real psychoanalysis' (Lacan 1988a: 77).

The main purpose of this paper was to examine the spatialities of psychoanalytic praxis but I would like to conclude by briefly discussing the ways in which a gay psychoanalytic spatial science may proceed beyond this paper. In addition to geography, there has been a trans- and interdisciplinary revival of psychoanalytic studies of race, class, politics, sexuality and popular culture (see, e.g., Bell 2000; Brooks and Woloch 2000; Dean and Lane 2001; Krips 1999; Lane 1998; Seshadri-Crooks 2000; Žižek 1998, 2001b). A significant group of these writers, the 'new Lacanians' (Mellard 1998), have endeavoured to elaborate on the radical theoretical shifts in Jacques Lacan's later work from The Ethics of Psychoanalysis seminar (1959-60) onwards (see Žižek 1999b). The new Lacanians, contra proponents of Derridean deconstruction and Foucauldian historicist-discourse analysis, strive to recuperate the radicality of Lacanian psychoanalytic theory from alleged misinterpretation. They argue that Lacanian theory is a viable alternative for theorizing AIDS, sexuality, ideology, political-economy, culture and history (see, e.g., Copjec 1995, 2003; Dean 2000; Fink 1995; Nobus 1999; Stavrakakis 1999; Verhaeghe 2001; Žižek 1999a, 2001a). This veritable boom in 
Lacanian publications has also been facilitated by the journal lacanian ink, the website $<$ http://www.lacan.com $>$ with its online journal, The Symptom, produced by the 'Lacanian Press Agency', and New York's Other Press and London's Karnac Press that merged in 1999 and have subsequently published over 400 psychoanalytic titles. The 'return to Lacan' also includes publications that offer incisive commentaries on three of Lacan's seminars (Barnard and Fink 2002; Feldstein, Fink and Jaanus 1995, 1996); a close reading of a pivotal Lacanian essay or 'écrit' (Van Haute 2002), Lacanian dictionaries (Evans 1996; Glowinski, Marks and Murphy 2001), re-translations of primary texts (Lacan 1999, 2002), and investigations into the status of contemporary Lacanian clinical practice (Dor 1999; Fink 1997; Mathelin 1999; Nasio 1998; Nobus 2000; Roudinesco 2002).

Perhaps the lack of engagement by geographers with this body of literature is the reason why geographers are so suspicious about Lacan. Gunnar Olsson, for example, confesses that 'with Jacques Lacan I am not yet at ease' (Olsson 1992: 24), while Nigel Thrift admits that he has not 'entirely given up on Lacan' (Thrift 1996: 21). The 'new Lacanians' should be able to help geographers respond to Blum and Nast's (2000) call that 'Lacan presents geographers with important theoretical challenges' and their question of how 'might geographers seize his analysis to find some crack within it ... [to] disrupt heteropatriarchy and spatial oppressions?' (Blum and Nast 2000: 201). The most outspoken 'new Lacanian' is Slavoj Žižek, who focuses on Lacan's lesserknown later writings. Žižek presents geographers with ways to not only search for cracks but attend to the sheer scope and heterogeneity of Lacan's fifty-year corpus that includes concepts such as jouissance, extimité, point de capiton, sînthome, sexuation and objet petit a that have hitherto been virtually ignored by geographers. No wonder geographers have mainly concentrated on the spatial flaws, limitations and superficiality of Lacan's 'theory!'

Composed of a 'Borromeian [sic] knot of Hegelian dialectics, Lacanian psychoanalytic theory, and contemporary criticism of ideology' (Žižek 1991a: 2), Žižek's work renders untenable the claim that 'psychoanalytic theory is inherently depoliticizing' (Aitken and Herman 1997: 71; cf. Stavrakakis 1999). Žižek’s writings encircle the 'symptoms of his enjoyment' that range from Hollywood melodramas to Mozartian operas. Žižek gaily puts to work Lacanian concepts to re-examine familiar themes in critical geography: 'sexuation' with sexuality and gender; 'symptom' and 'fantasy' with Marxist renderings of ideology and political economy; the Real and the objet petit a with cultural identity, difference, and the antagonisms of racist and nationalist violence. Furthermore, Žižek's work reminds us that 'there are no accepted psychoanalytic concepts which can be easily transposed into, superimposed onto, or mapped alongside, geographyregardless of the kind of geography' (Pile 1996: 81), and yet, he provokes us to accept the possibility of new kinds of geographies precisely because of the gaiety of psychoanalytic concepts.

Žižek claims there are urgent theoretical and therefore political incommensurabilities (despite their affinities, for example, with language, discourse and text) between psychoanalysis and the various 'poststructuralisms' of Derridean deconstruction, Foucauldian discursive-social constructionism, Butlerian performative theory and Deleuze-Guattarian schizoanalysis. Žižek repeatedly contends that the radicality and the fundamentals of (Lacanian) psychoanalysis have been thoroughly devalued, that is, assimilated or compromised by the various theoretical positions outlined above 
because of consistent misconceptions and misappropriations by highly influential 'poststructural' Anglo-American authors exemplified by the hesitant 'gay Lacanian' (Dean 2000: 179) Judith Butler. Furthermore, Žižek states (albeit on the back cover of a book) that 'the American reception of Lacan has taken place under conditions of deconstructionist-feminist-historicist theoretical censorship' (Fink 1995). Given the increasing comfort of critical geography's routine investments in psychoanalytic theory and alliances with 'poststructuralist' wisdom, would it not be a gay thing indeed to conjure the gravity of Žižek's protests?

\section{Acknowledgements}

This paper is based on presentations delivered at the Second Annual Graduate Student Women Studies Conference, University of Kentucky, 3-4 March 2000 and as part of psychoanalytic theme sessions at the Royal Geographical Society with the Institute of British Geographers Annual Conference, University of Plymouth, 2-5 January 2001. I would like to thank the session organizers Hester Parr and Chris Philo, and discussant David Sibley for their subsequent editorial efforts that facilitated the publication of this paper. I would also like to thank Lawrence Berg, John Clare and an anonymous reviewer for their perspicacious and valuable comments on an earlier draft of this paper. Finally, special thanks to Virginia Blum, John Paul Jones, and the department of geography at the University of Kentucky for significantly contributing to the thoughts and desire that enabled the joyful writing of this paper.

\section{Notes}

1 Žižek (2001b: 17) argues that Lacan was keenly aware of the historical context and role of capitalist society in allowing unique intersubjective relations in analysis. 'Money-paying the analyst-is necessary in order to keep him out of circulation, to avoid getting him involved in the imbroglio of passions which generated the patient's pathology. The psychoanalyst is thus effectively a kind of "prostitute of the mind", having recourse to money for the same reason some prostitutes like to be paid so that they can get sex without personal involvement, maintaining their distance ...'

2 I am grateful to Lawrence Berg for reminding me of the ineluctable modality of (idiographic) social space vis-àvis psychoanalytic praxes.

3 Die Fröhliche Wissenschaft was first translated into English as 'The Joyful Wisdom'. Walter Kaufman asserts that this is a mistranslation because Nietzsche gave an Italian subtitle to the 1887 second edition as ' $l a$ gaya scienza'. Kaufman refers to the book as 'The Gay Science' which has now become the most generally accepted translation. Kaufman also notes that the word 'gay' was not associated with homosexuality during Nietzsche's time (see Nietzsche 1974: 4-7).

4 Tim Dean (2000: 215) argues that 'psychoanalysis is a queer theory' and 'Lacan reads to me like a queer theorist avant la lettre, [but] the institutional history of psychoanalysis, particularly in the United States, has forestalled any such alliance' (2000: 226).

5 Echoing Lacan and Fink, I use the term 'analysand' rather than 'patient' or 'client' for the following reason: 'The-and ending of 'analysand' is a gerund form (likeing at the end of a word), which implies that it is the person in therapy who does the work of analyzing, not the analyst' (Fink 1997: 9).

6 The status of psychoanalysis as a science, while not addressed at length in this paper, is an important line of inquiry. Freud and Lacan were consistently preoccupied with this question (see, e.g., Althusser 2001; Felman 1987; Fink 1995; Frosh 1999; Lacan 1977b, 1989).

7 Given Lacan's intellectual affiliation to Hegel and Kojève, Lacan rarely draws on Nietzsche's works and when he does it is usually disparaging. Furthermore, unlike Freud, Lacan is hardly read with Nietzsche in mind (but see Babich 1996).

8 Cf. Diana Fuss's (1993) notion of 'gravitation' in her critique of Freud's psychoanalyses of women.

9 Cf. Jean-François Lyotard's (1993) discussion of the 'Little Girl Marx' and the 'Old Man Marx'. It is tempting (and therefore irresistible) to read Nietzsche's notorious descent into 'madness' as the failure of the 'Mother Nietzsche' to give birth to the Übermensch that precipitates the 'Little Child Nietzsche's' regressive 
feeling of omnipotence (primary narcissism) and the 'Old Man Nietzsche's' resentment-saturated sexism.

10 I use and capitalize the term 'Imaginary' (Imaginaire) throughout this paper in reference to one of Lacan's three interrelated psychic registers (see below). For Lacan, Imaginary dual or binary relations do not involve the imagination per se but rather concern themes such as the ego's fragmentation, narcissism, illusions of totality, rivalry, specular imagery, captation, sexual display, aggressiveness and meaning. For a discussion of the Imaginary relationship in analysis see Fink (1997: 31-33) and for a sustained exposition of the Imaginary central to Lacan's earlier works see, for example, Lacan (1988a: 73-199).

11 Žižek (1991a: 148) notes that Lacan regarded analysis as essentially an 'intersubjective' process in the $1950 \mathrm{~s}$ and later as a 'discourse' in the 1970s.

12 The noun 'Symbolic' refers to another of Lacan's psychic orders that approximate to totalizing spatialities of language, Law, communication, exchange, measurement, absence, lack, death and the unconscious.

13 My account of Lacanian analysis and the importance of desire mainly draws on Lacan's writing prior to Seminar XI (1964). Thereafter, Lacan conceives of analysis as an attempt to enable the subject to 'live out the drive' (vivre la pulsion) (see Fink 1997: 205-217; Miller 1996). Therefore, I do not examine how the Lacanian analysand must accept castration (relinquishing jouissance as the price to be paid for entering the symbolic register of speech) instead of demanding for compensation or retribution through the Other. In addition, my account does not consider Lacan's understandings of the various possible clinical functions of the phallus that is not 'really a penis_or, in Judith Butler's reading a dildo-[but] a giant red herring' (Dean 2000: 14).

14 It is important to note that in comparison to Winnicottian approaches, Lacanian analysts eschew occupying a maternal positionality, preferring the effects of paternal law (see Blum and Nast 1996, 2000). Lacan's notion of the objet petit a, however, derives in part from Winnicott's theorization of a 'transitional object'.

15 Lacan often considered the objet petit a his most important psychoanalytic formulation. Often translated into English as the 'object (little) a' the symbol a signifies the word autre or 'other' and in Lacan's works relates to the following: the ego's imaginary relation to the specular image, the formula of fantasy, the object of desire we seek in the other, an object that can never be attained, the 'object-cause' of desire, the object of anxiety, the irreducible reserve of the libido, surplus meaning and enjoyment, 'the semblance of being', and at the intersection of the Real, Symbolic, and Imaginary (see, e.g., Evans 1996: 124-126).

16 In Lacanian theory, 'enjoyment' is the closest literal translation of the French word 'jouissance' which connotes a fascinating, excessive, overwhelming and sexually charged pleasure. Given the nuances and difficulties of translation many anglophones retain the French term (see Kingsbury 2003).

17 The Real is the third and final Lacanian psychic register referred to in this paper. Often designated as Lacan's most elusory and baffling categories, the Real emblematizes contingent and barely elided encounters with that which fails, resists, subsists outside and is inassimilable to Symbolic representation. The Real is 'a certain limit which is always missed' (Žižek 1989: 173) and 'always returns to the same place' (Žižek 1989: 17). The impossibility for integrating, attaining or imagining the Real aligns it with trauma, obstacle, anxiety, materiality, hallucination and the undecideability of co-ordinating inside/outside demarcations.

18 In contrast to understanding temporality or time during analysis as predictable, predetermined, progressive and linear, Nasio (1998: 100) argues that the duration of analysis is a 'trajectory with two turns that link, in a spiral, the final point and the beginning of a cyclic and indeterminate process that is always open-ended'. These two overlapping temporal registers are psychical and logical that 'complement one another and describe a general movement of the analysis in a boundless, cyclical time'. Nasio compares this conception of time to the Neo-Platonist philosopher Plotinus (see also Lacan 1988b; Samuels 1990).

19 Cf. Bennington (1989) and Doel (1999: 123). See also Žižek (1990, 1991b).

\section{References}

Aitken, S. and Herman, T. (1997) Gender, power and crib geography: transitional spaces and potential places, Gender, Place and Culture: A Journal of Feminist Geography 4: 63-88.

Althusser, L. (2001) Freud and Lacan, in Lenin and Philosophy and other essays, trans. Brewster, B. New York: Monthly Review Press, pp. 133-150 (first published 1964).

Assoun, P. (2001) Freud and Nietzsche, trans. Coller, R.L. Brunswick, NJ: Athlone (first published 1980).

Babich, B. (1996) The order of the Real: Nietzsche and 
Lacan, in Pettigrew, D. and Raffoul, F. (eds) Disseminating Lacan. New York: State University of New York Press, pp. 43-68.

Barnard, S. and Fink, B. (eds) (2002) Reading Seminar XX: Lacan's Major Work on Love, Knowledge, and Feminine Sexuality. New York: State University of New York Press.

Barnes, T. (1996) Logics of Dislocation: Models, Metaphors, and Meanings of Economic Space. New York: Guilford.

Bell, D. (ed.) (2000) Psychoanalysis and Culture: A Kleinian Perspective. London: Routledge.

Benjamin, W. (1977) The Origin of German Tragic Drama, trans. Osborne, J. New York: Verso (first published 1963).

Bennington, G. (1989) Deconstruction is not what you think, in Papadakis, A., Cooke, C. and Benjamin, A. (eds) Deconstruction: Omnibus Volume. London: Macmillan, p. 84.

Blum, V. (1998) Ladies and gentleman: train rides and other Oedipal stories, in Nast, H. and Pile, S. (eds) Places Through the Body. New York: Routledge, pp. 263-280.

Blum, V. and Nast, H. (1996) Where's the difference? The heterosexualization of alterity in Henri Lefebvre and Jacques Lacan, Environment and Planning D: Society and Space 14: 559-580.

Blum, V. and Nast, H. (2000) Jacques Lacan's twodimensional subjectivity, in Crang, M. and Thrift, N. (eds) Thinking Space. New York: Routledge, pp. 183204.

Bondi, L. (1997) In whose words? On gender identities, knowledge and writing practices, Transactions of the Institute of British Geographers 22: 245-258.

Bondi, L. (1998) Sexing the city, in Fincher, R. and Jacobs, J. (eds) Cities of Difference. New York: Guildford, pp. 177-199.

Bondi, L. (1999) Stages on journeys: some remarks about human geography and psychotherapeutic practice, The Professional Geographer 51: 11-24.

Brenkman, J. (1993) Straight Male Modern: A Cultural Critique of Psychoanalysis. New York: Routledge.

Brooks, P. and Woloch, A. (eds) (2000) Whose Freud? The Place of Psychoanalysis in Contemporary Culture. New Haven, CT: Yale University Press.

Butler, J. (1993) Bodies that Matter: On the Discursive Limits of 'Sex'. New York: Routledge.

Cameron, L. (2001) Oral history in the Freud archives: incidents, ethics, and relations, Historical Geography 29: 38-44.
Chapelle, D. (1993) Nietzsche and Psychoanalysis. Albany: State University of New York.

Copjec, J. (1995) Read My Desire: Lacan Against the Historicists. Cambridge, MA: MIT Press.

Copjec, J. (2003) Imagine There's No Woman: Ethics and Sublimation. Cambridge, MA: MIT Press.

Davis, M. and Wallbridge, D. (1981) Boundary and Space: An Introduction to the Work of D.W. Winnicott. New York: Brunner/Mazel.

Dean, T. (2000) Beyond Sexuality. Chicago, IL: University of Chicago Press.

Dean, T. and Lane, C. (eds) (2001) Homosexuality and Psychoanalysis. Chicago, IL: University of Chicago Press.

Deleuze, G. (1983) Nietzsche and Philosophy, trans. Tomlinson, H. New York: Columbia University Press (first published 1962).

Deleuze, G. and Guattari, F. (1983) Anti-Oedipus: Capitalism and Schizophrenia. Trans. Hurley, R., Seem, M. and Lane, H. Minneapolis, MN: University of Minnesota Press (first published 1977).

Deleuze, G. and Guattari, F. (1987) A Thousand Plateaus: Capitalism and Schizophrenia, trans. Massumi, B. Minneapolis, MN: University of Minnesota Press (first published 1980).

Derrida, J. (1981) Spurs: Nietzsche's Style, trans. Harlow, B. Chicago, IL: University of Chicago Press (first published in 1976).

Derrida, J. (1987) Le facteur de la vérité, in The Post Card: From Socrates to Freud and Beyond, trans. Bass, A. Chicago, IL: University of Chicago Press (first published in 1975), pp. 413-496.

Derrida, J. (1998) Geopsychoanalysis: ‘ ... and the rest of the world', in Lane, C. (ed.) The Psychoanalysis of Race. New York: Columbia University Press, pp. 65-90.

Doel, M. (1999) Poststructuralist Geographies: The Diabolical Art of Spatial Science. Lanham, MD: Rowman \& Littlefield.

Doel, M. and Clarke, D. (2002) Lacan: the movie, in Cresswell, T. and Dixon, D. (eds) Engaging Film: Geographies of Mobility and Identity. Lanham, MD: Rowman \& Littlefield, pp. 69-93.

Dor, J. (1999) The Clinical Lacan. New York: Other Press.

Evans, D. (1996) An Introductory Dictionary of Lacanian Psychoanalysis. New York: Routledge.

Feldstein, R., Fink, B. and Jaanus, M. (eds) (1995) Reading Seminar XI: Lacan's Four Fundamental Concepts of Psychoanalysis. New York: State University of New York Press.

Feldstein, R., Fink, B. and Jaanus, M. (eds) (1996) Reading Seminars I and II: Lacan's Return to Freud. New York: State University of New York Press. 
Felman, S. (1987) Jacques Lacan and the Adventure of Insight: Psychoanalysis in Contemporary Culture. Cambridge, MA: Harvard University Press.

Fink, B. (1995) The Lacanian Subject: Between Language and Jouissance. Princeton, NJ: Princeton University Press.

Fink, B. (1997) A Clinical Introduction to Lacanian Psychoanalysis: Theory and Technique. Cambridge, MA: Harvard University Press.

Foucault, M. (1980) Questions on geography, in Kritzman, L.D. (ed.) Power/Knowledge: Selected Interviews and Other Writings, 1972-1977. New York: Routledge, pp. 255-267.

Foucault, M. (1984) What is Enlightenment?, in Rabinow, P. (ed.) The Foucault Reader. New York: Pantheon, pp. $32-50$.

Foucault, M. (1988) Madness and Civilization: A History of Insanity in the Age of Reason, trans. Sheridan, A. New York: Vintage Books (first published 1961).

Frosh, S. (1999) Psychoanalysis, science and 'truth', in Elliott, A. (ed) Freud 2000. New York: Blackwell, pp. 13-37.

Fuss, D. (1993) Freud's fallen women: identification, desire, and a 'Case of Homosexuality in a Woman', in Warner, M. (ed.) Fear of a Queer Planet. Minneapolis, MN: University of Minnesota Press, pp. 42-68.

Glowinski, H., Marks, Z. and Murphy, S. (eds) (2001) A Compendium of Lacanian Terms. London: Free Association Books.

Gregory, D. (1994) Geographical Imaginations. Cambridge, MA: Blackwell.

Gregory, D. (1997) Lacan and geography: the Production of Space revisited, in Benko, G. and Strohmayer, U. (eds) Space and Social Theory: Interpreting Modernity and Postmodernity. Malden, MA: Blackwell, pp. 203-231.

Guntrip, H. (1986) My experience of analysis with Fairbairn and Winnicott (how complete a result does psychoanalytic therapy achieve?), in Buckley, P. (ed) Essential Papers on Object Relations. New York: New York University Press, pp. 447-468.

Horkheimer, M. and Adorno, T.W. (1976) Dialectic of Enlightenment, trans. Cumming, J. New York: Continuum (first published 1969).

Irigaray, L. (1985) This Sex Which Is Not One, trans. Porter, C. and Burke, R. Ithaca, NY: Cornell University Press (first published 1977).

Irigaray, L. (1991) Marine Lover of Friedrich Nietzsche, trans. Gill, G. New York: Columbia University Press (first published 1980).

Kaufman, W. (1978) Nietzsche: Philosopher, Psychologist,
Antichrist (fourth edition). Princeton, NJ: Princeton University Press (first published 1950).

Kingsbury, P. (1999) The aesthetics of Apollonian and Dionysian space: Keeneland Race Course, a case study, MA thesis, Department of Geography, University of Kentucky.

Kingsbury, P. (2001) Lacanian Psychotherapy with Children: The Broken Piano by Catherine Mathelin, book review in disClosure a Journal of Social Theory 'childhood', 9: 149-150.

Kingsbury, P. (2003) Sun, sand, and psychoanalysis: Jamaican tourism and the politics of enjoyment, Geoforum (forthcoming).

Kingsbury, P. and Brunn, S.D. (2003) Freud, tourism, and terror: traversing the fantasies of post September 11 travel magazines, Journal of Travel and Tourism Marketing (forthcoming).

Krips, H. (1999) Fetish: An Erotics of Culture. Ithaca, NY: Cornell University Press.

Lacan, J. (1977b) In Miller, J. (ed.) The Four Fundamental Concepts of Psychoanalysis: The Seminar of Jacques Lacan, Book XI, trans. Sheridan, A. New York: W.W. Norton \& Co. (first published 1964).

Lacan, J. (1988a) In Miller, J. (ed.) Freud's Papers on Technique 1953-1954: The Seminar of Jacques Lacan Book I, trans. Forrester, J. New York: W.W. Norton \& Co. (first published 1975).

Lacan, J. (1988b) Logical time and the assertion of anticipated certainty: a new sophism, Newsletter of the Freudian Field 2: 4-22, trans. Fink, B. and Silver, M. (first published 1945).

Lacan, J. (1989) Science and truth, Newsletter of the Freudian Field 3: 4-29, trans. Fink, B. (first published 1966).

Lacan, J. (1999) In Miller, J. (ed.) On Feminine Sexuality the Limits of Love and Knowledge 1972-1973: Encore the Seminar of Jacques Lacan, Book XX, trans. Fink, B. New York: W.W. Norton \& Co. (first published 1975).

Lacan, J. (2000) Écrits: A Selection, trans. Sheridan, A. New York: W.W. Norton \& Co. (first published 1966).

Lacan, J. (2002) Écrits a Selection, trans. Fink, B. New York: W.W. Norton \& Co. (first published 1966).

Lane, C. (ed.) (1998) The Psychoanalysis of Race. New York: University of Columbia Press.

Space, trans. Smith, D. Oxford: Blackwell (first published 1974).

Lehrer, R. (1995) Nietzsche's Presence in Freud's Life and Thought: On the Origins of a Psychology of Dynamic Unconscious Mental Functioning. Albany, NY: State University of New York. 
Longhurst, R. (2001) Bodies: Exploring Fluid Boundaries. New York: Routledge.

Lyotard, F. (1993) Libidinal Economy, trans. Hamilton Grant, I. Bloomington, IN: University of Indiana Press (first published 1974).

Massey, D. (1994) Space, Place, and Gender. Minneapolis, MN: University of Minnesota Press.

Mathelin, C. (1999) Lacanian Psychotherapy with Children: The Broken Piano, trans. Fairfield, S. New York: Other Press (first published 1994).

Mellard, J.M. (1998) Lacan and the New Lacanians: Josephine Hart's Damage, Lacanian tragedy, and the ethics of jouissance, Publications of the Modern Language Association of America 113: 393-407.

Miller, J. (1996) Commentary on Lacan's text, in Feldstein, R., Fink, B. and Jaanus, M. (eds) Reading Seminars I and II: Lacan's Return to Freud. New York: State University of New York, pp. 417-421.

Nasio, J.D. (1998) Hysteria from Frend to Lacan: The Splendid Child of Psychoanalysis, trans. Fairfield, S. New York: Other Press (first published 1990).

Nast, H. (2000) Mapping the 'Unconscious': racism and the Oedipal family, Annals of the Association of American Geographers 90: 215-255.

Natter, W. and Jones, J.P. (1993) Signposts toward a poststructuralist geography, in Jones, J.P., Natter, W. and Schatzki, T.R. (eds) Postmodern Contentions: Epochs, Politics, Space. New York: Guilford, pp. 165204.

Nemeth, D.J. (1997) Extreme geography, The California Geographer 37: 10-31.

Nietzsche, F. (1974) The Gay Science, trans. Kaufman, W. New York: Vintage Books (first published 1882).

Nietzsche, F. (1999) Thus Spake Zarathustra, trans. Common, T. New York: Dover (first published 1883-1884).

Nobus, D. (ed.) (1999) Key Concepts of Lacanian Psychoanalysis. New York: Other Press.

Nobus, D. (2000) Jacques Lacan and the Freudian Practice of Psychoanalysis. New York: Routledge.

Olsson, G. (1992) Lines of Power/Limits of Language. Minneapolis, MN: University of Minnesota Press.

Picart, C. (1999) Resentment and the 'Feminine' in Niet Nietzsche's Politico-Aesthetics. University Park, PA: Penn State University Press.

Pile, S. (1996) The Body and the City: Psychoanalysis, Space and Subjectivity. New York: Routledge.

Pile, S. (1998) Freud, dreams and imaginative geographies, in Elliott, A. (ed.) Freud 2000. New York: Routledge, pp. 204-234.

Plotkin, M.B. (2002) Freud in the Pampas: The Emergence and Development of a Psychoanalytic Culture in Argentina. Stanford, CA: Stanford University Press.
Rickels, L.A. (2002) Nazi Psychoanalysis: Volume III Psy Fi. Minneapolis, MN: University of Minnesota Press.

Robinson, J. (2000) Feminism and the spaces of transformation, Transactions of the Institute of British Geographers 25: 285-301.

Rose, G. (1995) Distance, surface, elsewhere: a feminist critique of the space of phallocentric self/knowledge, Environment Planning D: Society and Space 13: 761-781.

Rose, G. (1996) As if the mirrors had bled: masculine dwelling, masculinist theory and feminist masquerade, in Duncan, N. (ed.) Bodyspace: Destabilizing Geographies of Gender and Sexuality. New York: Routledge, pp. 5674.

Rose, G. (2000) Psychoanalytic theory and geography, in Johnston, R.J., Gregory, D., Pratt, G. and Watts, M. (eds) The Dictionary of Human Geography (fourth edition). Malden, MA: Blackwell, pp. 653-655.

Rose, M. (2002) Landscape and labyrinths, Geoforum 33: 455-467.

Roudinesco, E. (2002) Why Psychoanalysis? New York: Columbia University Press.

Samuels, R. (1990) Logical time and Jouissance, Newsletter of the Freudian Field 4: 69-77.

Schneiderman, S. (1983) Jaques Lacan: The Death of an Intellectual Hero. Cambridge, MA: Harvard University Press.

Seshadri-Crooks, K. (2000) Desiring Whiteness: A Lacanian Analysis of Race. New York: Routledge.

Sibley, D. (1995) Geographies of Exclusion. New York: Routledge.

Stavrakakis, Y. (1999) Lacan and the Political. New York: Routledge.

Strohmayer, U. (1997) Belonging: spaces of meandering desire, in Benko, G. and Strohmayer, U. (eds) Space and Social Theory: Interpreting Modernity and Postmodernity. Malden, MA: Blackwell, pp. 162-185.

Thrift, N. (1996) Spatial Formations. Thousand Oaks, CA: Sage.

Van Haute, P. (2002) Against Adaptation: Lacan's 'Subversion' of the Subject. New York: Other Press.

Verhaeghe, P. (2001) Beyond Gender: From Subject to Drive. New York: Other Press.

Wilton, R.D. (1998) The constitution of difference: space and psyche in landscapes of exclusion, Geoforum 29: 173-185.

Winnicott, D.W. (1971) Playing and Reality. London: Tavistock.

Winnicott, D.W. (1984) Deprivation and Delinquency. London: Tavistock.

Wolfenstein, E.V. (2000) Inside/Outside Nietzsche: Psychoanalytic Explorations. Ithaca, NY: Cornell University Press. 
Yalom, I.D. (1993) When Nietzsche Wept: A Novel of Obsession. New York: Harper Perennial.

Žižek, S. (1989) The Sublime Object of Ideology. New York: Verso.

Žižek, S. (1990) How the Non-Duped Err, Qui Parle 4: 1-20.

Žižek, S. (1991a) For They Know Not What They Do: Enjoyment as a Political Factor. New York: Verso.

Žižek, S. (1991b) Looking Awry: An Introduction to Jacques Lacan Through Popular Culture. Cambridge, MA: MIT Press.

Žižek, S. (1997) The Plague of Fantasies. New York: Verso.

Žižek, S. (1998) Love Thy Neighbor? No, Thanks!, in Lane, C. (ed.) The Psychoanalysis of Race. New York: University of Columbia University Press, pp. 154-175.

Žižek, S. (1999a) The Ticklish Subject: The Absent Centre of Political Ontology. New York: Verso.

Žižek, S. (1999b) In Wright, E. and Wright, E. (eds) The Žižek Reader. Malden, MA: Blackwell.

Žižek, S. (2001a) Enjoy Your Symptom! Jacques Lacan in Hollywood and Out (second edition). New York: Routledge.

Žižek, S. (2001b) On Belief. New York: Routledge.

\section{Abstract translations}

La psychanalyse: science de l'espace gaie?

La psychanalyse est d'abord une pratique qui cherche à apaiser la détresse psychique. Tandis que les géographes sont familiers avec les approches théoriques de la psychanalyse, il existe peu d'analyses spatiales capables d'expliquer comment ces théories sont appliqués à travers les méthodes cliniques, techniques, et pratiques. Cet article propose qu'une étude de l'espace intense des sessions de psychanalyse peut enrichir la compréhension des théories de la psychanalyse et de leur utilité pour la recherche géographique critique. Je soutiens que les forces du jeu, désir et affect telles que conçues par Donald Winnicott et Jacques Lacan dans leur traitement des patients est la réalisation de-ou du moins comparable à-ce que Friedrich Nietzsche a dénommé le 'gai savoir'. En proposant des antécédents historiques à la psychanalyse, je m'inspire d'une constellation de sens associés à la catégorie 'gai' afin de cartographier certaines nuances spatiales de la pratique psychanalytique. L'article se concentre sur une étude de cas de Winnicott 're-maternant' un patient masculin ainsi que sur des études contemporaines d'analyses lacani- ennes d'enfants hystériques et autistiques. Afin d'obtenir des résultats cliniques positifs, ces psychanalyses utilisent d'un côté la gaieté de la joie, l'amour, le désir et les soins maternels et, de l'autre, l'approche moins gaie mais tout aussi thérapeutique de la douleur, l'agression, la séparation et le deuil. En conclusion, l'article suggère des voies futures pour les analyses psycho-spatiales gaies à travers une brève évaluation de la littérature interdisciplinaire des 'nouveaux lacaniens', en particulier les travaux de Slavoj Zizek.

Mots-clefs: Psychanalyse, gai, science, Lacan, Nietzsche.

\section{El psicoanálisis, una ciencia espacial gay?}

El psicoanálisis es principalmente una praxis dedicada a la curación de la angustia psíquica. Aunque los geógrafos conocen bien las ideas teóricas del psicoanálisis, son pocos los análisis de cómo emplear las teorías en sus métodos, técnicas y prácticas clínicas. La tesis de este papel es que una investigación de las intensas espacialidades en sesiones psicoanalíticos podría profundizar nuestro entendimiento de la teoría psicoanalítica y su relación con las investigaciones criticas geográficas. Sugiero que las fuerzas transferentes de juego, deseo y afecto en el tratamiento psicoanalítico de Donald Winnicott y Jaque Lacan de gente analizada constituyen una realización de o, por lo menos son comparables con, lo que Friedrich Nietzsche llamaba una 'ciencia gay'. Propongo un precedente histórico al psicoanálisis y hago uso de varios significados asociados con la categoría 'gay' para trazar algunos de los matices espaciales de la praxis psicoanalítica. El papel centra en los estudios de caso de Winnicott; de la mimada de un analizado macho y el análisis contemporáneo de Lacan de los histéricos y los niños autistas. Al esforzarse por alcanzar la eficacia clínica estos psicoanálisis utilizan, por un lado, la alegría del amor, deseo y el acto de mimar, y por el otro lado, lasno-tan-gay, y sin embargo, terapéuticas fuerzas del dolor, la agresividad, la separación y el duelo. El papel concluye por sugerir direcciones en que se podría llevar los análisis socio-espaciales gay en el futuro, a través de una breve evaluación de la literatura teórica social interdisciplinaria de los 'New Lacanians' y, en particular, el trabajo de Slavoj Zizek.

Palabras claves: Psicoanálisis, gay, ciencia, Lacan, Nietzsche. 
